\title{
Pembiayaan Kepemilikan Rumah (Sebuah Inovasi Pembiayaan Perbankan Syari'ah)
}

\author{
Oleh: Helmi Haris*
}

\begin{abstract}
Islam as a religion, have a significant influence to the Indonesian history, include here in the economic side. It is a fact that Islamic economic institutions, especially Islamic banks, are booming in Indonesia. There are many banks in Indonesia, willing to serve the costumer who want an Islamic banking transaction with the Islamic windows, or known as UUS (unit usaha syariah). The question now is, can the the Islamic banks in Indonesia attract the will of the people, that basicly want to gain profit. So, it is a necessary, to the stakeholder of the Islamic bank, to make an innovations in product.
\end{abstract}

Keywords: pembiayaan, perbankan, syariah dan inovasi.

\section{Pendahuluan}

Pada paruh pertama abad ke-20, di dunia Islam muncul gerakan NeoRevivalisme yang cukup berpengaruh terhadap peta pergerakan umat Islam dunia. Kemunculan gerakan ini pada dasarnya merupakan reaksi terhadap aksesakses sekularisme di dunia Islam dengan menolak westernisasi yang sudah mulai merasuk dunia Islam.

Termasuk dari bagian yang menjadi concern dari pergerakan ini adalah upaya

*Helmi Haris adalah peserta Program Pasca Sarjana UIN Sunan Kalijaga Yogyakarta, Konsentrasi Keuangan dan Perbankan Syari'ah. 
Helmi Haris: Pembiayaan Kepemilikan Rumah ...

untuk merumuskan suatu bank yang bebas dari bunga. Gerakan neo-Revivalisme yang begitu getol menyuarakan perlunya mendirikan suatu bank yang bebas bunga di antaranya adalah gerakan Ikhwanul Muslimin di Mesir dan gerakan Jama'at Islami di anak benua India. Menurut kedua pergerakan ini, Islam telah memiliki suatu kerangka kerja yang komprehensif, yang mencakup di dalamnya aturan-aturan transaksi dalam bidang ekonomi.

Dari pemikiran pergerakan Neo-Revivalisme inilah perbankan Islam mulai dilirik sebagai alternatif pilihan untuk menggantikan perbankan berbasis bunga. Pergerakan ini juga dianggap sebagai bagian dari faktor-faktor yang mendorong kemunculan perbankan Islam, di samping beberapa faktor lainnya, yaitu; kekayaan negara-negara teluk (yang sebagian besar adalah negara Islam) karena mereka mempunyai minyak yang melimpah serta adanya interpretasi tradisional tentang riba yang diterima oleh negara-negara Islam. ${ }^{1}$

Dalam konteks Indonesia, wacana pendirian bank syari'ah di Indonesia bermula ketika diadakannya suatu lokakarya yang bertema "Bunga Bank dan Perbankan” yang diselenggarakan oleh Majelis Ulama' Indonesia (MUI) pada tanggal 18 sampai 20 Agustus 1990 di Cisarua, Bogor ${ }^{2}$, yang pada akhirnya memunculkan BMI (Bank Muamalat Indonesia) sebagai pioner perbankan syari' ah yang didirikan di Indonesia.

Keberadaan bank-bank syari' ah di Indonesia semakin mendapat legitimasi dengan disahkannya berbagai undang-undang yang mendukung, seperti Undangundang No 7 Tahun 1992 tentang Perbankan sebagaimana yang telah diubah dalam Undang-undang Nomor 10 Tahun 1998 dan Undang-undang Nomor 23 Tahun 1999 tentang Bank Indonesia yang memungkinkan bagi bank-bank konvensional untuk memberlakukan dual banking system, dengan membuka unit usaha syari'ah.

Perbankan syari'ah di Indonesia, dilihat dari perangkat hukum maupun dari pertumbuhan jumlah perbankan syari'ah, memang sudah cukup berkembang. Namun jika dilihat dari rasio jumlah penduduk Indonesia yang mayoritas muslim, jumlah perbankan syari'ah terasa masih kurang. Bank-bank syari'ah di Indonesia masih cenderung menggarap pasar loyalis ${ }^{3}$, yang potensinya sebesar Rp. 10 trilyun. Jumlah ini masih relatif kecil jika dibandingkan dengan potensi pasar floating ${ }^{4}$

${ }^{1}$ Lihat Abdullah Saeed (2004), Menyoal Bank Syariah; Kritik Atas Interpretasi Bunga Kaum Neo Revivalis, (Jakarta: Paramadina), hlm. 6.

2 Muslimin H. Kara (2005), Bank Syariah di Indonesia; Analisis Kebijakan Pemerintah Indonesia terhadap Perbankan Syariah, (Yogyakarta: UII Press), hlm. 106.

${ }^{3}$ Nasabah loyalis adalah nasabah yang dikategorikan memang mempunyai loyalitas terhadap perbankan syari'ah, terlepas dari keuntungan atau kerugiaan yang mungkin bisa diperoleh dengan menjadi nasabah bank syari'ah.

${ }^{4}$ Nasabah floating (mengambang) adalah nasabah yang menginginkan keuntungan tanpa melihat apakah bank yang dia gunakan adalah bank syari'ah atau bank konvensional. Sehingga bank yang menawarkan keuntunganlah yang akan dia pilih. 
(mengambang) yang diprediksi mencapai angkan Rp. 720 trilyun. $^{5}$

Berdasarkan pemikiran itulah, maka perlu dipikirkan oleh praktisi dan teoritisi perbankan syari'ah untuk memformulasikan suatu inovasi produk perbankan sehingga mampu menarik minat nasabah floating tersebut. Salah satu inovasi tersebut adalah produk pembiayaan pemilikan rumah (KPR) yang mulai banyak ditawarkan oleh bank-bank syari'ah.

\section{A. KPR di Perbankan Syari'ah.}

Keberadaan Bank Syari'ah ${ }^{6}$ di Indonesia relatif masih cukup baru, di mana bank umum syari' ah yang pertama kali berdiri adalah BMI (Bank Muamalat Indonesia) yang berdiri pada tahun 1992. Adapun sekarang, perkembangan bank syari'ah Indonesia mengalami kenaikan yang diindikasikan dengan keberadaan dua bank umum syari'ah, (yaitu; BMI /Bank Muamalat indonesia dan BSM/ Bank Syari'ah Mandiri) serta banyaknya bank-bank konvensional yang membuka unit usaha syari'ah (UUS).

Pada prinsipnya, bank syari ah adalah sama dengan perbankan konvensional, yaitu sebagai instrumen intermediasi yang menerima dana dari orang-orang yang surplus dana (dalam bentuk penghimpunan dana) dan menyalurkannya kepada pihak yang membutuhkan (dalam bentuk produk pelemparan dana). Sehingga produk-produk yang disediakan oleh bank-bank konvensional, baik itu produk penghimpunan dana (funding) maupun produk pembiayaan (financing), pada dasarnya dapat pula disediakan oleh bank-bank syariah.

Produk pembiayaan KPR yang digunakan dalam perbankan syari'ah memiliki berbagai macam perbedaan dengan KPR (Kredit Kepemilikan Rumah) di perbankan konvensional. Hal ini merupakan implikasi dari perbedaan prinsipal yang diterapakan perbankan syari'ah dan perbankan konvensional, yaitu konsep bagi hasil dan kerugian (profit and loss sharing) sebagai pengganti sistem bunga perbankan konvensional. Dalam produk pembiayaan kepemilikan rumah ini, terdapat beberapa perbedaan antara perbankan syari'ah dan perbankan konvensional, di antaranya adalah; pemberlakuan sistem kredit dan sistem mark $u p$, kebolehan dan ketidakbolehan tawar menawar (bargaining position) antara nasabah dengan bank, prosedur pembiayaan dan lain sebagainya.

Dari segi pengistilahan, untuk produk pembiayaan pemilikan rumah, perlu dipikirkan suatu bentuk pengistilahan yang relevan. Karena istilah KPR cenderung memunculkan asumsi terjadinya kredit, padahal dalam perbankan syari'ah tidak menggunakan sistem kredit. Untuk menghindari hal itu (tetapi

${ }^{5}$ Harian Kompas tanggal 7 Agustus 2003.

${ }^{6}$ Istilah Bank Syari'ah ini dikenal di Indonesia. Sedangkan di beberapa negara Islam yang lain, konsep seperti ini dikenal dengan nama Bank Islam. 
Helmi Haris: Pembiayaan Kepemilikan Rumah ...

tetap menggunakan istilah $\mathrm{KPR}^{7}$ ), beberapa bank syari'ah (seperti BTN Syari'ah) memaknai KPR dengan "Kebutuhan Pemilikan Rumah".

Dalam menjalankan produk KPR, bank syari'ah memadukan dan menggali skim-skim transaksi yang dibolehkan dalam Islam dengan operasional KPR perbankan konvensional. ${ }^{8}$ Adapun skim yang banyak digunakan oleh perbankan syari'ah di Indonesia dalam menjalankan produk pembiayaan KPR adalah skim murabahah, istisna' dan ijaroh, khususnya ijarah muntahiya bi tamlik (IMBT).

\section{KPR Syariab Yang Menggunakan Skim Murabahab.}

KPR Syariah menggunakan sistem berbasis murabahah (jual beli). ${ }^{9}$ Secara etimologi, murabahah berasal dari kata ribh, yang berarti keuntungan. ${ }^{10}$ Sedangkan dalam pengertian terminologis, murabahah adalah jual beli barang seharga barang tersebut ditambah keuntungan yang disepakati antara penjual dengan pembeli. ${ }^{11}$

Dalam praktek perbankan syari'ah, murabahah selalu menggunakan jenis al- bay' bisaman ajjil atau muajjal (jenis pembayaran secara tangguh atau cicilan. Jadi, murabahah merupakan transaksi jual beli, di mana bank bertindak sebagai penjual dan nasabah sebagai pembeli. Akad jenis ini adalah salah satu bentuk akad bisnis yang mencari keuntungan bersifat pasti (certainly return) dan telah diketahui dimuka (pre-determiner return). Murabahah sendiri merupakan penjualan sesuatu barang dengan harga asal dengan tambahan keuntungan sejumlah yang disepakati bersama. ${ }^{12}$ Dengan sistem murabahah yang diterapkan dalam pembiayaan KPR ini berarti pihak bank syari'ah harus memberitahukan harga perolehan atau harga asal rumah yang dibeli dari developer kepada nasabah KPR Syari'ah dan menentukan suatu tingkat keuntungan (profitmargin) sebagai tambahan. ${ }^{13}$ Di antara bank-bank syari' ah di Indonesia yang menggunakan skim

${ }^{7}$ Karena di masyarakat luas sudah terpolakan bahwa produk perbankan yang melayani pembiayaan kepemilikan rumah adalah KPR. Faktor familier inilah yang kemudian menjadi alasan bank-bank syari'ah tetap menggunakan istilah KPR.

${ }^{8}$ Bentuk penggalian dan pemaduan ini bertujuan untuk menciptakan suatu bentuk transaksi pembiayaan pemilikan rumah yang sesuai dengan prinsip Islam. Adapun yang dijadikan acuan adalah pelaksanaan KPR di bank-bank konvensional, karena diakui atau tidak keberadaan bank-bank syari'ah pada awalnya adalah merupakan wujud kekurangpuasan umat Islam terhadap bank konvensional sehingga mengupayakan bentuk transaksi perbankan yang sesuai dengan prinsip Islam.

${ }^{9}$ Artikel resmi BTN dalam www.btn.co.id, tanggal 10 Mei 2006.

${ }^{10}$ Abdullah al-Muslih \& Shalah ash-Shawi (2004), Fikih Ekonomi Keuangan Islam, (Jakarta: Daarul Haq), hlm. 198.

${ }^{11}$ Adiwarman A. Karim (2003), Bank Islam; Analisis Fiqih dan Keuangan, (Jakarta: IIIT Indonesia), hlm 161.

${ }^{12}$ BIMB Institute of Research and Training Sdn.Bhd (1998), Konsep Syariah dalam Sistem Perbankan, (Kuala Lumpur: Perniagaan Rita), hlm. 16.

${ }^{13}$ Muhammad Syafi'i Antonio (1999), Bank Syariah Wacana Ulama \& Cendekiawan, 
murabahah dalam pembiayaan KPR adalah BNI Syari'ah, BSM (Bank Syari'ah Mandiri) serta BTN Syari'ah.

Skema pembiayaan KPR Syariah dengan skim murabahah ${ }^{14}$

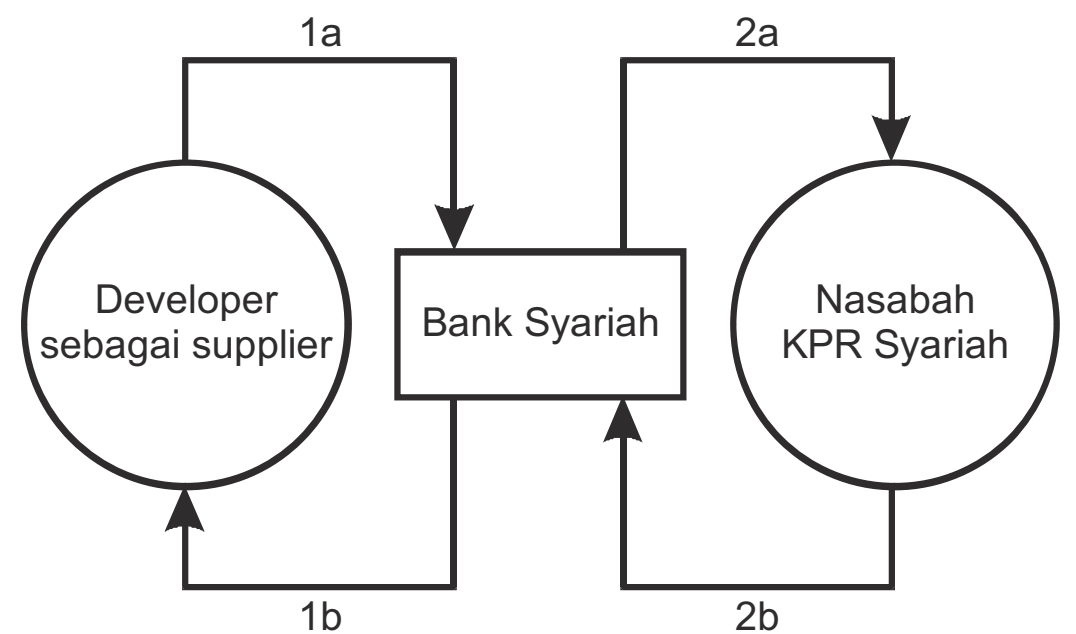

Keterangan:

1a Developer perumahan menjual rumah kepada pihak bank syari'ah secara tunai.

16 Bank syari'ah membeli kepada developer selaku supplier secara tunai.

$2 a$ Bank syari'ah menjual rumah sebesar harga pokok/ asal ditambah keuntungan yang disepakati bersama, kepada nasabah KPR Syari'ah secara tangguh/ angsuran.

$2 b$ Nasabah membeli kepada bank syariah secara angsuran.

\section{a. Rukun dan Syarat KPR Syari'ab yang menggunakan skim murababab.}

Dalam semua pembiayaan murabahah, termasuk pembiayaan KPR Syari'ah, terdapat rukun yang dikristalisasikan sebagai berikut:

1) Pihak yang berakad
a) Penjual
b) Pembeli

2) Objek yang diakadkan

a) Barang diperjualbelikan

b) Harga jual/keuntungan

3) Akad/sighat

a) Serah (ijab)

(Jakarta: Bank Indonesia), hlm. 21.

${ }^{14}$ Skema ini diadaptasi dari skema murabahah, Adiwarman A. Karim, Op.Cit. 
Helmi Haris: Pembiayaan Kepemilikan Rumah ...

b) Terima (qabul). ${ }^{15}$

Dengan mengacu pada skim murabahah, dapat disimpulkan syarat-syarat yang harus dipenuhi dalam transaksi KPR Syari'ah adalah sebagai berikut:

1) Pihak bank harus memberitahukan biaya pembelian rumah kepada nasabah KPR Syari'ah.

2) Kontrak transaksi KPR Syari'ah ini haruslah sah.

3) Kontrak tersebut harus terbebas dari riba

4) Pihak bank syari'ah harus memberikan kejelasan tentang rumah yang dijadikan obyek transaksi KPR Syari'ah.

5) Penjual harus menjelaskan semua hal yang berkaitan dengan proses perolehan barang tersebut. ${ }^{16}$

Sedangkan persyaratan yang ditetapkan oleh Majelis Ulama' Indonesia (MUI) tentang aplikasi murabahah dalam perbankan syari' ah, ${ }^{17}$ yaitu:

1) Bank dan nasabah harus mengadakan akad murabahah yang bebas riba.

2) Barang yang diperjualbelikan tidak diharamkan oleh Syari'at Islam.

3) Bank membiayai sebagian atau seluruh harga pemberian barang yang telah disepakati kualitasnya.

4) Bank membeli barang yang diperlukan nasabah atas nama bank sendiri, bukan atas nama pembeli atau nasabah dan pembelian ini harus sah dan bebas dari riba.

5) Bank harus menyampaikan semua hal yang berkaitan dengan pembelian, misalnya, jika pembelian dilakukan secara hutang.

6) Bank kemudian menjual barang tersebut kepada nasabah (pesanan) dengan harga jual senilai harga perolehan (harga beli ditambah dengan pajak pertambahan nilai/ PPN, biaya angkut dan biaya lain yang terkait dengan pembelian) ditambah dengan keuntungan. Dalam kaitan ini, bank harus memberitahukan secara jujur harga pokok barang kepada nasabah berikut biaya yang diperlukan.

7) Nasabah membayar harga barang yang telah disepakati tersebut pada jangka waktu tertentu yang telah disepakati.

8) Untuk mencegah terjadinya penyalahgunaan atau kerusakan akad tersebut, pihak bank dapat mengadakan perjanjian secara khusus dengan nasabah.

9) Jika bank hendak mewakilkan kepada nasabah untuk membeli barang sendiri dari pihak ketiga, maka akad jual beli murabahah harus dilakukan setelah

${ }^{15}$ Tim PPS. IBI (2003), Konsep Produk dan Implementasi Operasional Bank Syariah, (Jakarta: Djambatan), hlm. 77.

${ }^{16}$ Syafi' Antonio (2001), Bank Syariah; Dari Teori ke Praktek, (Jakarta: Gema Insani Press), hlm. 102.

${ }^{17}$ Majelis Ulama' Indonesia (2003), Himpunan Fatwa-Fatwa Dewan Syariah Nasional, (Jakarta: DSN MUI bekerjasama dengan Bank Indonesia), hlm. 17. 
barang secara prinsip menjadi milik bank.

\section{b. Penentuan Keuntungan Pembiayaan Murababab KPR di Bank Syari'ab}

Sebagaimana pada perbankan konvensional, fungsi bank syari'ah juga merupakan lembaga intermediasi yang menghimpun dana dari para penabung atau investor atau masyarakat yang kelebihan dana dan menyalurkan kepada masyarakat yang membutuhkannya. Perbedaan pokok bank konvensional dengan bank syari'ah terletak pada dominasi produk atau scheme prinsip bagi hasil (uncertainly in return) yang melandasi sistem operasionalnya baik dalam perhimpunan (funding) maupun pelemparan (financing) dananya.

Produk KPR Syari'ah merupakan salah satu produk pelemparan dana pada bank syari'ah, berdasarkan -salah satunya- skim murabahah, yang perolehan keuntungan disebut margin atau mark-up yang bersifat tetap selama masa perjanjian (certainly return). ${ }^{18}$ Karena besarnya keuntungan atau margin sudah diketahui sejak awal, maka tinggi rendahnya dipengaruhi oleh tingkat keuntungan per satu kali transaksi dan besarnya jumlah transaksi dalam satu periode. ${ }^{19}$ Besarnya cicilan yang harus dibayar oleh nasabah KPR Syari'ah adalah bersifat tetap (tidak berubah) selama masa transaksi yang telah disepakati. Dengan demikian, konsumen tidak terbebani fluktuasi suku bunga yang terus mengalami perubahan. Meskipun suku bunga bergolak, cicilan KPR Syariah tetap sama. ${ }^{20}$

Bentuk keuntungan atau margin dalam pembiayaan KPR Syari ah adalah dalam bentuk nominal rupiah, namun dapat juga dipersentasekan jika ingin mengetahui berapa sebenarnya besarnya persentase margin dibandingkan harga perolehan. Hal ini dapat dibenarkan karena transaksi murabahah adalah transaksi yang obyeknya terdapat barang yang diperjualbelikan sehingga jenis transaksi ini bentuk bisnis yang nyata pada sektor riil yang menciptakan nilai tambah (economic value added). ${ }^{21}$

Dengan merujuk pada skim murabahah, penentuan harga atau keuntungan dan angsuran dalam KPR Syari' ah haruslah memenuhi persyaratanpersyaratan berikut: ${ }^{22}$

1) Keuntungan atau mark-up yang diminta bank harus diketahui oleh nasabah.

2) Harga jual bank adalah harga beli (harga perolehan) bank ditambah kontrak.

${ }^{18}$ Certainly return adalah perolehan keuntungan yang dapat dipastikan di awal

${ }^{19}$ Adiwarman A. Karim, Op.Cit., hlm. 253.

${ }^{20} \mathrm{Hal}$ ini diungkapkan oleh Willy Aryati, Kepala Divisi BTN Syariah, di Metro TV tanggal 3 Mei 2006.

${ }^{21}$ Muhammad (2003), Manajemen Bank Syariah, (Yogyakarta: UPP AMP YKPN), hlm. 69.

${ }^{22}$ Tim DSN-MUI, Op.Cit., hlm. 17. 
Helmi Haris: Pembiayaan Kepemilikan Rumah ...

keuntungan.

3) Harga jual tidak boleh berubah selama masa perjanjian.

4) Sistem pembayaran dan jangka waktunya disepakati bersama.

\section{KPR Syari'ah Yang Menggunakan Skim Isthisna'}

Skim fiqh yang juga dapat digunakan oleh perbankan syari'ah dalam menjalankan produk pembiayaan pemilikan rumah adalah skim istisna'. Salah satu bank yang memiliki produk pembiayaan KPR Syari'ah dengan mengadopsi skim istisna' ini adalah BTN Syari'ah. Dalam fatwa DSN-MUI dijelaskan bahwa jual beli istisna' adalah akad jual beli dalam bentuk pemesanan pembuatan barang tertentu dengan kriteria dan persyaratan tertentu yang disepakati antara pemesan (pembeli/mustasni) dan penjual (pembuat/șani). ${ }^{23}$

Pada prinsipnya, pembiayaan istisna' merupakan transaksi jual beli dengan cara pembayaran mengansur (installment) yang hampir sama dengan transaksi murabahah. Perbedaannya terletak pada penyerahan barang yang menjadi objek transaksi. Dalam murabahah, barang diserahkan di muka, sedangkan dalam isthisna', barang diserahkan di belakang, yakni pada akhir periode pembiayaan. Hal ini terjadi karena biasanya barang belum dibuat atau belum wujud.

Dalam KPR dengan skim ini, bank bertindak sebagai agen pemesan dan penjual. Bank memesan kepada developer, sebuah rumah yang kriteria-kriterianya sudah ditentukan terlebih dahulu oleh nasabah. Rumah yang dimaksudkan ini adalah rumah yang memang belum wujud dan baru dimulai pembangunannya setelah ada pemesanan dari pihak bank. Pihak bank kemudian menjual rumah tersebut kepada nasabah secara angsuran, tetapi penyerahannya adalah pada waktu akhir periode pembayaran.

Adapun harga jual bank adalah harga awal rumah tersebut dari pengembang ditambah biaya-biaya yang telah dikeluarkan oleh bank beserta tingkat keuntungan yang besarnya haruslah disepakati terlebih dahulu antara nasabah dengan bank. Ketentuan mengenai besarnya harga jual rumah kepada nasabah ini berlaku selama akad berlangsung.

Skema KPR dengan skim isthisna ${ }^{24}$

${ }^{23}$ Ibid.

${ }^{24}$ Diadaptasi dari skema isțisna’. Lihat, Muhammad (2002), Op. Cit, hlm. 93. 


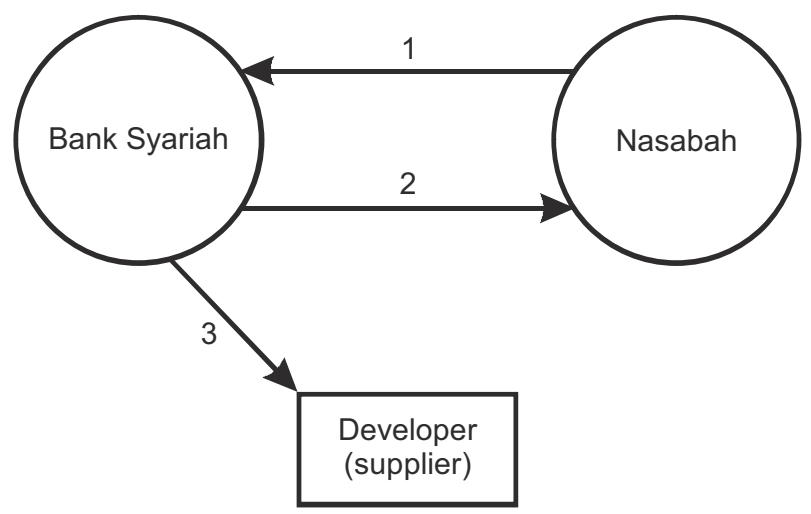

Keterangan:

a. Nasabah memesan rumah kepada bank dengan kriteria tertentu yang telah ditentukan.

b. Bank membeli rumah kepada developer perumahan ( selaku supplier) sesuai dengan kriteria yang telah ditentukan oleh nasabah.

c. Bank menjual barang kepada nasabah (tetapi penyerahan barangnya pada akhir pembiayaan) dan nasabah membayar dengan cara mengangsur.

Karena KPR ini menggunakan skim istisna', maka akad KPR ini harus memenuhi beberapa ketentuan umum sistem jual beli istisna', yaitu: ${ }^{25}$

a. Spesifikasi barang (dalam hal ini adalah rumah) yang dipesan harus jelas, seperti; tipe, kelengkapan, ukuran dan lain sebagainya.

b. Harga jual yang telah disepakati, dicantumkan dalam akad dan tidak boleh berubah selama berlakunya akad.

c. Jika terjadi perubahan kriteria pesanan dan terjadi perubahan harga setelah akad ditandatangani, maka seluruh biaya tambahan tetap ditanggung oleh nasabah.

\section{KPR Syari'ah Yang Menggunakan Skim Ijarab Muntabiya Bi Tamlik (IMBT)}

Skim transaksi lain yang dapat digunakan untuk pembiayaan kepemilikan rumah adalah skim ijaroh muntahiya bi tamlik (IMBT). Ijarah atau sering juga disamakan dengan pure leasing adalah pemberian kesempatan kepada penyewa untuk mengambil kemanfaatan dari barang sewaan untuk jangka waktu tertentu dengan imbalan yang besarnya telah disepakati. ${ }^{26}$ Pada prinsipnya, transaksi ijarah dilandasi adanya perpindahan manfaat (hak guna), bukan pemindahan kepemilikan (hak milik). Jadi pada dasarnya prinsip ijarah sama saja dengan prinsip jual beli, tetapi perbedaannya terletak pada objek transaksinya. Bila dalam transaksi jual beli, objek transaksinya adalah barang, pada ijarah objek

${ }^{25}$ Ibid, hlm. 92.

${ }^{26}$ Karnaen Perwataatmadja dan Muhammad Syafi'i Antonio (1999), Apa dan Bagaimana Bank Islam, (Yogyakarta: PT. Dana Bhakti Prima Yasa), hlm. 29. 
Helmi Haris: Pembiayaan Kepemilikan Rumah ...

transaksinya adalah barang maupun jasa.

Berdasarkan skim ijarah ini, bank syari'ah menyewakan rumah, sebagai objek akad, kepada nasabah. Meskipun pada prinsipnya tidak terjadi pemindahan kepemilikan (hanya pemanfaatan rumah), tetapi pada akhir masa sewa bank dapat menjual atau menghibahkan rumah yang disewakannya kepada nasabah. Model transaksi seperti ini, dalam perbankan syari' ah dikenal dengan nama ijarah muntahiya bi tamlik/ IMBT (sewa yang diikuti atau diakhiri dengan perpindahan kepemilikan).

Ijarah muntahiya bi tamlik (IMBT) merupakan kombinasi antara sewa menyewa (ijarah) dengan jual beli atau hibah di akhir masa sewa. Dalam ijaroh muntahiya bi tamlik (IMBT) ini terjadi pemindahan hak milik barang, dengan dua cara: ${ }^{27}$

a. Ijarah dengan janji akan menjual pada akhir masa sewa.

b. Ijarah dengan janji akan memberikan hibah pada akhir masa sewa.

Dalam praktek transaksi ijarah, pilihan untuk menjual barang di akhir masa sewa, biasanya diambil bila kemampuan finansial penyewa untuk membayar sewa relatif kecil. Karena sewa yang dibayarkan kecil, akumulasi nilai sewa yang sudah dibayarkan sampai akhir periode sewa belum mencukupi harga beli barang tersebut beserta margin keuntungan yang ditetapkan oleh pihak bank. Karena itu, untuk menutupi kekurangan tersebut, bila pihak penyewa ingin memiliki barang tersebut, ia harus membeli barang itu di akhir masa sewa.

Sedangkan alternatif pilihan untuk menghibahkan barang di akhir masa sewa biasanya diambil bila kemampuan finansial penyewa untuk membayar sewa relatif lebih besar. Karena sewa yang dibayarkan relatif besar, akumulasi sewa di akhir periode sewa sudah mencukupi untuk menutup harga beli barang dan margin keuntungan yang telah ditetapkan oleh pihak bank. Dengan demikian, pihak bank dapat menghibahkan barang tersebut di akhir masa periode sewa kepada pihak penyewa.

Nilai sewa yang berlaku harus berdasarkan harga barang dan besarnya cicilan barang tersebut, sehingga dapat diketahui berapa harga jual di akhir masa menyewakan atau apakah dapat langsung dengan hibah.

Skema KPR dengan skim Al-Ijarah ${ }^{28}$

${ }^{27}$ Adiwarman Karim (2004), Bank Islam: Analisis Figh dan Keuangan, (Jakarta: RajaGrafindo Persada), hlm. 155.

${ }^{28}$ Diadaptasi dari skema ijarah. Lihat, M. Syafi'i Antonio (2000), Op.Cit, hlm. 119. 


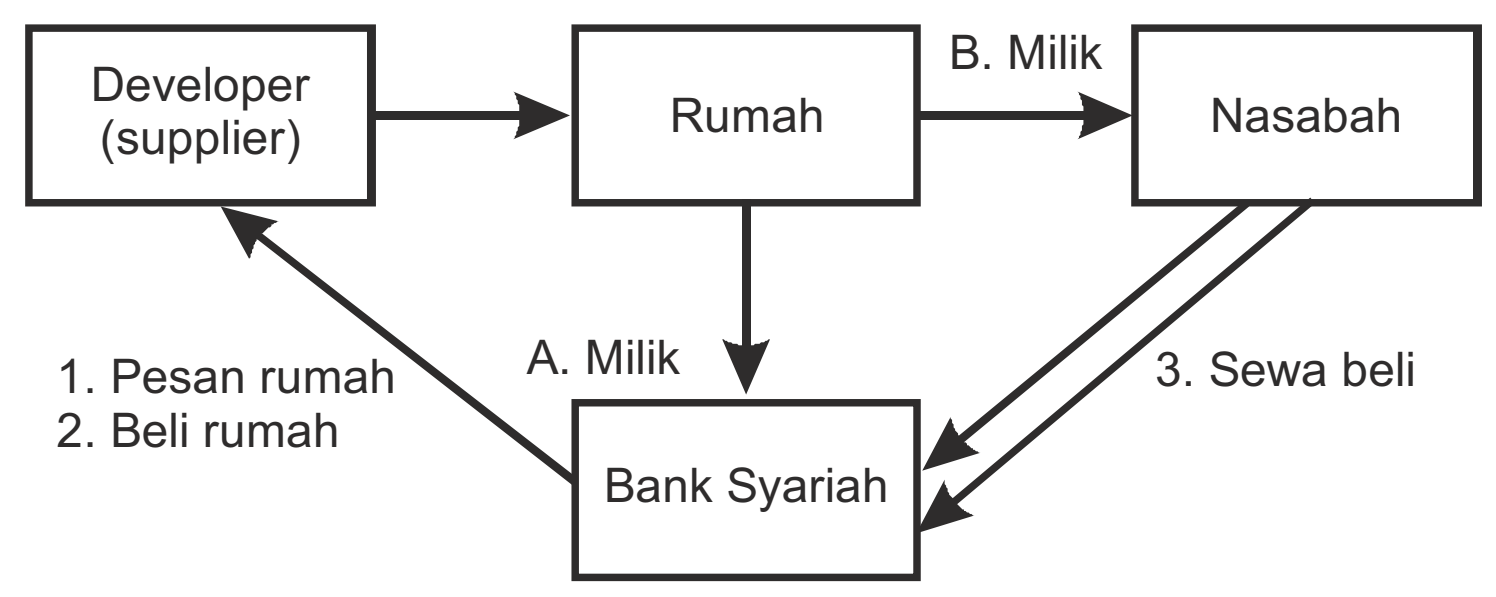

Berdasarkan pola pemindahan hak milik dalam ijarah muntahiya bi tamlik (IMBT), maka pembiayaan KPR yang dijalankan oleh perbankan syari'ah menggunakan pola kedua, yaitu; transaksi ijarah dengan adanya perjanjian antara pihak bank dengan nasabah bahwa bank akan menghibahkan rumah (yang dibiayai KPR) pada akhir masa sewa kepada nasabah.

Salah satu bank syari'ah di Indonesia yang menggunakan skim ijarah muntahiya bi tamlik dalam mengeluarkan produk pembiayaan KPR adalah BMI (Bank Muamalat Indonesia). ${ }^{29}$

\section{Pemberlakuan Agunan}

Dalam literatur fiqh, jaminan selain barang dikenal dengan istilah kafalah. Kafalah bermakna pemberian jaminan bagi orang yang berutang ketika belum mampu membayar. ${ }^{30}$ Jaminan dalam bentuk barang dikenal dengan gadai $(\mathrm{rahn})$. Gadai adalah menahan salah satu harta peminjam sebagai jaminan atas pinjaman yang diterimanya. Status gadai terbentuk saat terjadinya akad hutang-piutang yang dibarengi dengan penyerahan jaminan. ${ }^{31}$

Jaminan atau agunan dimaksud untuk menjaga agar calon pembeli tidak main-main atau serius dalam memesan barang. Jaminan juga sebagai bentuk komitmen atau ikatan antara nasabah atau pembeli dengan bank syari'ah selaku penjual karena pada prakteknya pengembalian kewajiban pembeli kepada bank syari'ah secara angsuran memerlukan waktu yang relatif lama. ${ }^{32}$ Bank syari'ah selaku pihak penjual dapat meminta kepada nasabah atau pembeli suatu jaminan untuk dipegangnya. Dalam teknik operasionalnya, barang-barang yang dibeli

${ }^{29}$ www. muamalatbank.co.id

${ }^{30}$ Habib Nazir dan Muhammad Hassanuddin (2004), Ensiklopedi Ekonomi dan Perbankan Syariah, (Jakarta: Kaki Langit), hlm. 300.

${ }^{31}$ Muhammad Syafi'i Antonio (1999), Op.Cit, hlm. 215.

${ }^{32}$ Muhammad Syafi'i Antonio, Op.Cit., hlm. 125. 
Helmi Haris: Pembiayaan Kepemilikan Rumah ...

dapat menjadi salah satu jaminan yang dapat diterima untuk pembayaran hutang.

Landasan dibolehkannya memintakan jaminan dalam transaksi-transaksi syari'ah adalah Q.S. AL-Baqarah (2): 283. Adapun yang menjadi jaminan dalam produk pembiayaan KPR Syari'ah ini adalah sertifikat rumah yang sedang diangsur oleh nasabah.

Dengan jaminan ini bank mempunyai posisi tawar jika nantinya terjadi wanprestasi yang dilakukan oleh nasabah KPR. Jika nasabah KPR tidak membayar angsuran sampai jumlah tertentu atau mungkin berhenti mengangsur, maka jaminan ini dapat dipakai untuk menutup kekurangan yang seharusnya diterima oleh pihak bank. Dengan demikian, pemberlakuan jaminan dapat memberikan rasa aman bagi investor (dalam hal ini adalah nasabah penabung) bahwa dananya tidak akan hilang begitu saja jika nasabah peminjam wan prestasi, karena adanya asset yang dipegang oleh pihak bank.

\section{Penutup}

Keberagaman serta perbedaan penggunaan skim fiqh dalam pembiyaan pemilikan rumah (KPR) oleh bank syari'ah-bank syari'ah di Indonesia memiliki nilai negatif dan nilai positif. Nilai negatifnya adalah; memunculkan kesan bahwa tidak ada suatu otoritas khusus yang menangani operasional perbankan syari'ah di Indonesia sehingga muncul berbagai variasi produk pembiayaan kepemilikan rumah. Pembiayaan kepemilikan rumah ini, di bank syari'ah yang satu dengan bank syari'ah yang lain berbeda. Namun sebenarnya di Indonesia sudah ada sebuah lembaga (di bawah naungan MUI), yaitu Dewan syari'ah Nasional yang merumuskan aplikasi skim-skim kontrak dalam bidang Hukum Islam ke dalam praktek lembaga-lembaga keuangan syari'ah, semisal bank.

Segi positifnya adalah; dengan berbagai macam variasi pembiayaan kepemilikan rumah yang ditawarkan oleh bank-bank syariah berarti calon nasabah mempunyai berbagai alternatif pilihan untuk memiliki rumah dengan cara yang sesuai dengan keiginannya.

\section{DAFTAR PUSTAKA}

Abdullah Saeed (2004). Menyoal Bank Syariah; Kritik Atas Interpretasi Bunga Kaum Neo Revivalis. Jakarta: Paramadina.

al-Muslih, Abdullah \& ash-Shawi, Shalah (2004). Fikih Ekonomi Keuangan Islam. Jakarta: Daarul Haq.

Adiwarman A. Karim (2003). Bank Islam; Analisis Fiqih dan Keuangan. Jakarta: IIIT Indonesia.

(2001). Ekonomi Islam Suatu Kajian Kontemporer. Jakarta: Gema 
Helmi Haris: Pembiayaan Kepemilikan Rumah ...

Insani Press.

BIMB Institute of Research and Training Sdn.Bhd. (1998). Konsep Syariah dalam Sistem Perbankan. Kuala Lumpur: Perniagaan Rita.

Habib Nazir dan Muhammad Hassanuddin (2004). Ensiklopedi Ekonomi dan Perbankan Syari'ah. Jakarta: Kaki Langit.

Karnaen Perwataatmadja dan Muhammad Syafi'i Antonio (1999). Apa dan Bagaimana Bank Islam. Yogyakarta: PT. Dana Bhakti Prima Yasa.

Muslimin H. Kara (2005). Bank Syariah di Indonesia; Analisis Kebijakan Pemerintah Indonesia terhadap Perbankan Syariah. Yogyakarta: UII Press.

M. Syafi'i Antonio (2000). Bank Syariah dari Teori Ke Praktek. Jakarta: Gema Insani Press.

(1999). Bank Syariah Wacana Ulama \& Cendekiawan. Jakarta: Bank Indonesia.

Muhammad (2002). Manajemen Bank Syari'ah. Yogyakarta: UPP AMP YKPN.

Tim DSN-MUI (2003). Himpunan Fatwa Dewan Syariah Nasional. Jakarta: DSN MUI bekerjasama dengan Bank Indonesia.

Tim PPS IBI (2003). Konsep Produk dan Implementasi Operasional Bank Syariah. Jakarta: Djambatan. 